\title{
Effects of microcystin-containing cyanobacterial extract on hematological and biochemical parameters of common carp (Cyprinus carpio L.)
}

\author{
Anna Sieroslawska • Anna Rymuszka • \\ Josef Velisek • Barbara Pawlik-Skowrońska • \\ Zdenka Svobodova • Tadeusz Skowroński
}

Received: 7 June 2011/Accepted: 30 December 2011/Published online: 7 January 2012

(C) The Author(s) 2012. This article is published with open access at Springerlink.com

\begin{abstract}
The aim of the study was to assess the effects of a cyanobacterial extract containing microcystins (MCs) on selected hematological and biochemical parameters in common carp (Cyprinus carpio L.), as well as to determine the accumulation of toxins in fish tissues. The fish were immersed for 5 days in water containing toxins at a final concentration of $12 \mu \mathrm{g} / \mathrm{L}$ of microcystin LR equivalent. Microcystin LR residues were detected in fish liver, reaching 207, 238 and $260 \mathrm{ng} / \mathrm{g}$ f.w. of the tissues taken $24 \mathrm{~h}$, $72 \mathrm{~h}$ and 5 days after the end of intoxication, respectively. The most substantial changes were found in fish plasma, including increases in creatine kinase, lactate dehydrogenase, ammonia, glucose, aspartate
\end{abstract}

A. Sieroslawska $(\varangle) \cdot$ A. Rymuszka $\cdot$ T. Skowroński Department of Physiology and Ecotoxicology, Institute of Biotechnology, The John Paul II Catholic University of Lublin, ul. Konstantynów 1 H, 20-708 Lublin, Poland e-mail: ansie@kul.lublin.pl

J. Velisek · Z. Svobodova

Faculty of Fisheries and Protection of Waters, South Bohemian Research Center of Aquaculture and Biodiversity of Hydrocenoses, Research Institute of Fish Culture and Hydrobiology, University of South Bohemia in Ceske Budejovice, Zatisi 728/II, 38925 Vodnany, Czech Republic

B. Pawlik-Skowrońska · T. Skowroński

Polish Academy of Sciences, Centre for Ecological Research, Experimental Station, Niecała 18/3, 20-080 Lublin, Poland aminotransferase and alanine aminotransferase levels. A decline of about $50 \%$ in lysozyme activity was observed by the end of the experimental period. Moreover, a marked increase in ceruloplasmin activity was detected $24 \mathrm{~h}$ after the end of intoxication with a subsequent decrease in its activity after $72 \mathrm{~h}$ and 5 days. This study concludes that not only consumption of food containing toxins but also MCs dissolved in water may pose a threat to fish health. Additionally, detected changes in lysozyme and ceruloplasmin activity may have distinct effects in fish resistance against pathogens or oxidative stress, which should be taken into account in the future studies.

Keywords Cyanobacterial water blooms .

Microcystin LR · Cyprinus carpio · Hematological profile $\cdot$ Biochemical profile $\cdot$ Microcystin tissue accumulation

\section{Introduction}

The increasing eutrophication of surface waters is one of the main causes of massive cyanobacterial water blooms observed worldwide in the last few decades. Some species of cyanobacteria produce toxins, which may have different chemical structures and toxic activity and induce various biological effects. It is estimated that, of the 2,000 described cyanobacterial species, nearly 50 may be toxic, and the variability in this regard relates even to the various strains of the 
same species (Ernst 2008). Approximately $75 \%$ of water blooms are found to be toxic (Sivonen and Jones 1999). Cyanotoxins, according to the nature of their toxic activity, are divided into hepatotoxins, neurotoxins, cytotoxins, dermatotoxins, irritants and gastrointestinal toxins (Briand et al. 2003). Hepatotoxic microcystins (MCs), with the most toxic isoform, microcystin LR (MC-LR), are among the most frequently detected cyanotoxins of high stability in the environment (Blaha et al. 2009; Briand et al. 2003). MCs are widely known to accumulate in the food chain (Xie et al. 2005; Chen et al. 2009a), negatively affecting both wild life and human beings (Matsunaga et al. 1999; Carmichael et al. 2001; Qiu et al. 2007; Chen et al. 2009b).

Due to their natural environment, fish can be exposed to cyanotoxins via multiple routes, at different concentrations and during different periods of time. There are many reports on the negative effects of MCs on fish, including disturbances in developmental processes, behavioral changes, hepatotoxic, nephrotoxic or immunotoxic effects (Oberemm et al. 1999; Malbrouck and Kestemont 2006; Baganz et al. 2004; Ernst 2008). Changes in biochemical and hematological parameters were described in certain studies, in which fish were exposed to MCs either naturally (Kopp et al. 2005, 2009, 2010; Qiu et al. 2009) or experimentally, via oral or intraperitoneal (i.p.) route (Li et al. 2004; Zhang et al. 2007). The first route of exposure is more natural, but the observed changes may result not only from MC toxicity but also from such factors occurring during cyanobacterial blooms, as hypoxia, a high $\mathrm{pH}$ level, high ammonia concentrations or other, untested agents present in water. On the other hand, i.p. injection does not reflect actual kinetics and trends of changes arising during MC intoxication of fish in the environment. Oral intoxication, although considered the main way of exposure on cyanotoxins, at least for herbivorous and omnivorous fish, does not include other possibilities of toxin uptake, such as entering via the gills. Moreover, when whole cyanobacteria cells are administered orally, the expected level of exposure to cyanotoxins may be overestimated, as it was described that viable cells were detected after their passage through the alimentary tract in cyprinids (Jancula et al. 2008).

The aim of the study was to assess the influence of the immersion of Cyprinus carpio L. in water containing MCs at environmentally relevant concentrations
(Blaha et al. 2010) on fish blood indices, as well as to establish the toxin accumulation in selected tissues after 5 days of exposure. Moreover, the study intended to investigate the possibility of the toxins to affect the activity of lysozyme, one of the basic components of fish innate immunity, and ceruloplasmin, the acute phase protein.

\section{Materials and methods}

\section{MC-containing extract}

MC-containing extract was obtained from the cyanobacterial scum consisting of Microcystis spp. (M. aeruginosa, M. flos-aquae, M. natans) and, to a lesser extent, Aphanizomenon flos-aquae, collected from a dam reservoir located in SE Poland. The total MC content in the cyanobacterial scum was determined as the equivalent of MC-LR by gas chromatography/ mass spectrometry (GC/MS, Varian) according to the method described by Pawlik-Skowrońska et al. (2008). The calibration curve for quantitative analysis was prepared with standard MC-LR (Alexis Biochemicals).

Fish and experimental setup

The studies were conducted on 48 healthy common carp (C. carpio L.) of either sex, with a mean body weight of $30.1 \pm 8.5 \mathrm{~g}$, which were originally bred at the Research Institute of Fish Culture and Hydrobiology, Vodnany, University of South Bohemia, the Czech Republic. In this study, the principles of laboratory animal care and the national laws 246/1992 "Animal Welfare" on the protection of animals were followed (Ref. no. 22761/2009-17210). Fish were divided into three groups - two experimental and one control group, 16 carp in each-and kept in 40-L tanks at $17.5 \pm 1{ }^{\circ} \mathrm{C}, \mathrm{pH} 7.7 \pm 0.1$ and dissolved oxygen $81.3 \pm 2 \%$ with $10 \mathrm{~h}$ : $14 \mathrm{~h}$ light/dark cycle. Fish were not fed during the whole experimental period. MC-containing cyanobacterial extract was added to the experimental tanks in order to gain the final concentration of $12 \mu \mathrm{g} / \mathrm{L}$ of MC-LR equivalent. Water was changed daily. MC concentration in the tank water was confirmed daily with the use of ELISA kit (EnviroGard, USA), in accordance with the producer protocol. After 5 days of exposure, fish were 
transferred to the MC-free water. Blood and tissue sampling was conducted after $24 \mathrm{~h}, 72 \mathrm{~h}$ and 5 days once exposure had ceased.

\section{Sampling procedure}

Blood samples for further analyses were taken from vena caudalis with heparin at $50 \mathrm{IU} / \mathrm{mL}$. Whole livers, spleens, kidneys, as well as muscle and gill samples of the same size from each fish were taken, pooled inside each experimental group and frozen at $-80^{\circ} \mathrm{C}$ for the determination of $\mathrm{MC}$ concentrations.

\section{MC determination in fish tissues}

Toxin identification and quantification in fish tissues were carried out using a high-performance liquid chromatography (HPLC) system (Prominence, Shimadzu) equipped with a Diode Array Detector (DAD SPD M20A) operating at $238 \mathrm{~nm}$. MC-LR, MC-LA, MC-YR, MC-LY, MC-RR, MC-LW and MC-LF standards (Alexis, Biochemicals) were used for calibration curve preparation.

Pooled samples of each tissue were weighed and extracted through homogenization in $75 \%$ methanol (Merck, pure p.a.) containing $0.002 \mathrm{M} \mathrm{HCl}$ and ultrasonication (2-3 times for $10 \mathrm{~min}$ ). In order to remove an excess of lipid compounds, the methanol extracts were treated two times with n-hexane (1:1, $\mathrm{v} / \mathrm{v})$. The hexane layers were discarded, and the obtained extracts were evaporated to dryness in glass vials and stored at $-20^{\circ} \mathrm{C}$. HPLC analysis of MCs in the purified extracts was performed on LiChroCART 125-3 Purospher RP-18 column (5 $\mu \mathrm{m}$, Merck) with mobile phases: A-water acidified with $0.05 \%$ trifluoroacetic acid (TFA, Merck) and B-aqueous acetonitrile with $0.05 \%$ TFA, according to Lawton et al. (1994). The gradient of phase B was $30-100 \%$ with a flow rate $0.7 \mathrm{~mL} / \mathrm{min}$. The $\mathrm{MC}$ detection limit was $60 \mathrm{ng} / \mathrm{g}$ f.w.

\section{Blood assays}

The following parameters in blood were tested: the erythrocyte count (RBC), hemoglobin concentration $(\mathrm{Hb})$, hematocrit value (PCV), mean erythrocyte volume (MCV), mean erythrocyte hemoglobin $(\mathrm{MCH})$, mean color concentration (MCHC), leukocyte count (WBC) and differential leukocyte count. All determinations were carried out according to the methods described in Svobodova et al. (1991). Blood plasma, obtained by blood centrifugation at $400 \mathrm{~g}$ for $15 \mathrm{~min}$ at $4^{\circ} \mathrm{C}$, was stored at $-80^{\circ} \mathrm{C}$ for further biochemical analyses.

Biochemical determinations of the glucose (GLU), the total amount of proteins (TP), albumins (ALB), the total amount of globulin (GLOB), ammonia $\left(\mathrm{NH}_{3}\right)$, aspartate aminotransferase (AST), alanine aminotransferase (ALT), creatine kinase (CK), lactate dehydrogenase (LDH), calcium $\left(\mathrm{Ca}^{2+}\right)$, magnesium $\left(\mathrm{Mg}^{2+}\right)$, inorganic phosphate (PHOS), alkaline phosphatase (ALP), triglycerides (TRIG) and gammaglutamyl transferase (GGT) were conducted with a VET-TEST 8008 analyzer (IDEXX Laboratories Inc., USA).

Lysozyme activity in fish plasma was determined by a turbidimetric assay according to Day et al. (2007), with slight modifications. For standard curve preparation, lyophilized lysozyme from the hen egg white (Sigma) was used. The standard concentrations of the enzyme, studied samples and PBS (as a negative control) were added in triplicate to the 96-well microtiter plate. Then, a fresh suspension of Micrococcus lysodecticus $(0.2 \mathrm{mg} / \mathrm{mL}$ in $0.1 \mathrm{M}$ phosphate buffer, $\mathrm{pH}$ 6.2) was added quickly to each well. The initial OD (T0) was taken immediately at $450 \mathrm{~nm}$ on the BioRad 550 microplate reader, and the plate was left for $20 \mathrm{~min}$ at room temperature until the next OD reading (T20). OD values at T20 were subtracted from $\mathrm{OD}$ at $\mathrm{T} 0$ and converted to $\mu \mathrm{g} / \mathrm{mL}$ using the linear equation from the standard curve.

Ceruloplasmin $(\mathrm{Cp})$ activity in plasma was measured as p-phenylenediamine (PPD) oxidase activity, according to Pelgrom et al. (1995). In short, fish plasma was mixed with $0.1 \%$ PPD (Sigma) solution in $0.2 \mathrm{M}$ acetate buffer ( $\mathrm{pH} 5.5)$ and incubated for $30 \mathrm{~min}$ at $37^{\circ} \mathrm{C}$ in the dark. The reaction was stopped by the addition of $0.1 \%$ sodium azide (Sigma), and the $\mathrm{Cp}$ activity was measured colorimetrically at $540 \mathrm{~nm}$ using a BioRad SmartSpec 3000 spectrophotometer.

\section{Statistical analysis}

Statistical analysis was performed by a nonparametric Mann-Whitney $U$ test with Statistica 8.0 software (StatSoft, USA). $P$ values $<0.05$ were considered to be statistically significant. 


\section{Results}

During the experiment, both control and MC-exposed carp showed normal behavior. There were no signs of respiratory distress such as rapid ventilation, increased rate of gill opercular movements or fish floating at the surface of the water. There were no mortalities during the experiment.

MC determination in fish tissues

Among all examined isoforms of MCs, only MC-LR was detected and exclusively in fish liver, in which it reached $207 \pm 128,238 \pm 7$ and $260 \pm 43$ ng/g f.w. after $24 \mathrm{~h}, 72 \mathrm{~h}$ and 5 days, respectively. In the other studied organs, that is, spleens, kidneys, gills, as well as in the muscle samples, the toxin was below the limit of detection.

\section{Blood assays}

The visible changes in blood cell parameters after the end of intoxication included a significant decrease $(P<0.05)$ in the monocyte count seen after $24 \mathrm{~h}$, gradually increasing during the ensuing days. A statistically significant increase in MCHC after $24 \mathrm{~h}$ was detected, while MCV and $\mathrm{MCH}$ remained unchanged, compared to the control group (Table 1). The values for RBC, Hb, PCV and WBC were similar among all groups.

More pronounced changes were detected in biochemical indices (Table 2). A significant $(P<0.05)$ increase in the GLU level was seen, but only $24 \mathrm{~h}$ after the intoxication had ceased. Levels of CK and LDH in intoxicated fish plasma were significantly $(P<0.05)$ higher during the entire period of analysis, with an observed upward trend. The activity of CK detected in the plasma of experimental fish constituted 134, 151 and $170 \%$ of the enzyme activity in the control group after $24 \mathrm{~h}, 72 \mathrm{~h}$ and 5 days, respectively. Similar increase was seen in the LDH level. Moreover, after $24 \mathrm{~h}$, also a tendency to increase the activity of AST $(P=0.058)$, ALT $(P=0.066)$ and $\mathrm{NH}_{3}(P=0.052)$ was observed. After $72 \mathrm{~h}$ and 5 days, respectively, the changes were already statistically significant, reaching 216 and $250 \%$ of the level of AST activity in control fish and 300 and $364 \%$ of ALT activity. In the case of $\mathrm{NH}_{3}$, the observed increase was rather stable and reached about $120 \%$ of the level in control fish. The remaining parameters (TP, ALB, GLOB, $\mathrm{Ca}^{+2}, \mathrm{Mg}^{2+}$,

Table 1 Blood cell parameters of the fish intoxicated with the cyanobacterial extract containing $12 \mu \mathrm{g}$ of MC-LR equivalent per $1 \mathrm{~L}$ for 5 days in the comparison with the control fish

\begin{tabular}{|c|c|c|c|c|c|c|c|}
\hline \multirow[t]{2}{*}{ Parameter } & \multirow[t]{2}{*}{ Units } & \multicolumn{2}{|l|}{$24 \mathrm{~h}$} & \multicolumn{2}{|l|}{$72 \mathrm{~h}$} & \multicolumn{2}{|l|}{5 days } \\
\hline & & Control group & $\begin{array}{l}\text { Experimental } \\
\text { group }\end{array}$ & Control group & $\begin{array}{l}\text { Experimental } \\
\text { group }\end{array}$ & Control group & $\begin{array}{l}\text { Experimental } \\
\text { group }\end{array}$ \\
\hline $\mathrm{RBC}$ & $\mathrm{T} / \mathrm{L}$ & $1.50 \pm 0.26$ & $1.43 \pm 0.18$ & $1.58 \pm 0.31$ & $1.67 \pm 0.30$ & $1.57 \pm 0.34$ & $1.51 \pm 0.23$ \\
\hline $\mathrm{Hb}$ & $\mathrm{g} / \mathrm{L}$ & $64.39 \pm 11.48$ & $67.76 \pm 10.71$ & $61.17 \pm 11.59$ & $62.33 \pm 11.26$ & $67.42 \pm 12.93$ & $72.06 \pm 10.93$ \\
\hline PCV & $1 / \mathrm{L}$ & $0.29 \pm 0.04$ & $0.28 \pm 0.05$ & $0.29 \pm 0.06$ & $0.29 \pm 0.05$ & $0.27 \pm 0.06$ & $0.29 \pm 0.06$ \\
\hline $\mathrm{MCV}$ & $\mathrm{fl}$ & $198.62 \pm 17.14$ & $198.24 \pm 56.24$ & $188.31 \pm 59.99$ & $180.83 \pm 42.29$ & $178.38 \pm 49.12$ & $195.62 \pm 36.68$ \\
\hline $\mathrm{MCH}$ & pg & $43.07 \pm 3.83$ & $48.35 \pm 11.42$ & $40.55 \pm 14.12$ & $37.97 \pm 7.92$ & $43.76 \pm 7.85$ & $48.22 \pm 6.64$ \\
\hline $\mathrm{MCHC}$ & $\mathrm{g} / \mathrm{L}$ & $217.88 \pm 23.05$ & $246.94 \pm 26.42 *$ & $216.67 \pm 27.94$ & $212.68 \pm 26.03$ & $251.50 \pm 32.73$ & $249.07 \pm 20.70$ \\
\hline WBC & $\mathrm{G} / \mathrm{L}$ & $9.26 \pm 2.95$ & $10.51 \pm 3.92$ & $17.86 \pm 10.21$ & $13.66 \pm 3.86$ & $11.75 \pm 4.27$ & $11.86 \pm 5.71$ \\
\hline Lymphocytes & $\mathrm{G} / \mathrm{L}$ & $7.89 \pm 3.22$ & $9.78 \pm 3.81$ & $16.72 \pm 10.07$ & $12.82 \pm 3.86$ & $10.81 \pm 3.93$ & $12.95 \pm 4.46$ \\
\hline Monocytes & $\mathrm{G} / \mathrm{L}$ & $0.56 \pm 0.41$ & $0.13 \pm 0.17 *$ & $0.30 \pm 0.19$ & $0.18 \pm 0.16$ & $0.33 \pm 0.31$ & $0.24 \pm 0.17$ \\
\hline $\begin{array}{l}\text { Band } \\
\text { neutrophils }\end{array}$ & $\mathrm{G} / \mathrm{L}$ & $0.71 \pm 0.71$ & $0.51 \pm 0.48$ & $0.53 \pm 0.36$ & $0.52 \pm 0.17$ & $0.32 \pm 0.29$ & $0.18 \pm 0.18$ \\
\hline $\begin{array}{l}\text { Segmented } \\
\text { neutrophils }\end{array}$ & $\mathrm{G} / \mathrm{L}$ & $0.10 \pm 0.08$ & $0.10 \pm 0.10$ & $0.13 \pm 0.11$ & $0.13 \pm 0.13$ & $0.17 \pm 0.22$ & $0.14 \pm 0.16$ \\
\hline Basophiles & $\mathrm{G} / \mathrm{L}$ & 0.00 & 0.00 & $0.21 \pm 0.26$ & $0.04 \pm 0.12$ & $0.12 \pm 0.33$ & 0.00 \\
\hline
\end{tabular}

$n=5$, mean \pm SD. Time after the end of intoxication

* Statistically significant at $P<0.05$ 
Table 2 Biochemical parameters of the fish intoxicated with the cyanobacterial extract containing $12 \mu \mathrm{g}$ of MC-LR equivalent per $1 \mathrm{~L}$ for 5 days in the comparison with the control fish

\begin{tabular}{|c|c|c|c|c|c|c|c|}
\hline \multirow[t]{2}{*}{ Parameter } & \multirow[t]{2}{*}{ Units } & \multicolumn{2}{|l|}{$24 \mathrm{~h}$} & \multicolumn{2}{|l|}{$72 \mathrm{~h}$} & \multicolumn{2}{|l|}{5 days } \\
\hline & & Control group & $\begin{array}{l}\text { Experimental } \\
\text { group }\end{array}$ & Control group & $\begin{array}{l}\text { Experimental } \\
\text { group }\end{array}$ & Control group & $\begin{array}{l}\text { Experimental } \\
\text { group }\end{array}$ \\
\hline GLU & $\mathrm{mmol} / \mathrm{L}$ & $3.96 \pm 0.90$ & $5.05 \pm 0.87^{*}$ & $3.95 \pm 0.32$ & $3.88 \pm 0.72$ & $3.86 \pm 0.26$ & $3.82 \pm 0.38$ \\
\hline $\mathrm{TP}$ & $\mathrm{g} / \mathrm{L}$ & $36.50 \pm 7.13$ & $37.25 \pm 6.73$ & $36.12 \pm 6.29$ & $36.25 \pm 3.28$ & $36.87 \pm 3.80$ & $37.00 \pm 2.88$ \\
\hline ALB & $\mathrm{g} / \mathrm{L}$ & $6.87 \pm 3.31$ & $6.12 \pm 3.44$ & $7.00 \pm 4.00$ & $6.24 \pm 2.19$ & $6.12 \pm 2.75$ & $6.37 \pm 2.45$ \\
\hline GLOB & $\mathrm{g} / \mathrm{L}$ & $29.37 \pm 3.38$ & $31.12 \pm 3.56$ & $30.25 \pm 3.41$ & $30.00 \pm 1.51$ & $31.87 \pm 3.6$ & $30.62 \pm 1.06$ \\
\hline $\mathrm{NH}_{3}$ & $\mu \mathrm{mol} / \mathrm{L}$ & $549.75 \pm 73.29$ & $648.12 \pm 109.83$ & $552.25 \pm 34.76$ & $657.12 \pm 81.16^{*}$ & $561.37 \pm 40.94$ & $664.62 \pm 44.00^{*}$ \\
\hline AST & $\mu \mathrm{kat} / \mathrm{L}$ & $3.82 \pm 2.23$ & $5.64 \pm 1.67$ & $3.52 \pm 0.66$ & $7.62 \pm 0.69^{*}$ & $3.64 \pm 0.42$ & $9.09 \pm 0.56^{*}$ \\
\hline ALT & $\mu \mathrm{kat} / \mathrm{L}$ & $0.10 \pm 0.04$ & $0.20 \pm 0.13$ & $0.10 \pm 0.04$ & $0.30 \pm 0.13^{*}$ & $0.11 \pm 0.04$ & $0.40 \pm 0.12 *$ \\
\hline $\mathrm{CK}$ & $\mu \mathrm{kat} / \mathrm{L}$ & $11.98 \pm 1.91$ & $16.06 \pm 1.95^{*}$ & $12.05 \pm 1.26$ & $18.20 \pm 1.27^{*}$ & $12.17 \pm 1.28$ & $20.70 \pm 0.77^{*}$ \\
\hline $\mathrm{LDH}$ & $\mu \mathrm{kat} / \mathrm{L}$ & $17.80 \pm 0.80$ & $19.14 \pm 0.67^{*}$ & $17.72 \pm 0.47$ & $22.00 \pm 1.43^{*}$ & $17.66 \pm 0.72$ & $24.25 \pm 0.81^{*}$ \\
\hline $\mathrm{Ca}^{2+}$ & $\mathrm{mmol} / \mathrm{L}$ & $2.51 \pm 0.17$ & $2.56 \pm 0.24$ & $2.54 \pm 0.16$ & $2.58 \pm 0.37$ & $2.65 \pm 0.32$ & $2.67 \pm 0.28$ \\
\hline $\mathrm{Mg}^{2+}$ & $\mathrm{mmol} / \mathrm{L}$ & $1.02 \pm 0.22$ & $1.06 \pm 0.21$ & $1.01 \pm 0.17$ & $0.97 \pm 0.17$ & $0.95 \pm 0.23$ & $0.96 \pm 0.14$ \\
\hline PHOS & $\mathrm{mmol} / \mathrm{L}$ & $1.34 \pm 0.11$ & $1.40 \pm 0.11$ & $1.37 \pm 0.09$ & $1.43 \pm 0.10$ & $1.50 \pm 0.23$ & $1.52 \pm 0.21$ \\
\hline ALP & $\mu \mathrm{kat} / \mathrm{L}$ & $0.75 \pm 0.12$ & $0.77 \pm 0.12$ & $0.73 \pm 0.11$ & $0.80 \pm 0.15$ & $0.82 \pm 0.19$ & $0.87 \pm 0.21$ \\
\hline TRIG & $\mathrm{mmol} / \mathrm{L}$ & $0.93 \pm 0.10$ & $0.95 \pm 0.08$ & $0.93 \pm 0.11$ & $0.96 \pm 0.20$ & $0.98 \pm 0.14$ & $0.96 \pm 0.20$ \\
\hline GGT & $\mathrm{nmol} / \mathrm{L}$ & $12.56 \pm 7.75$ & $10.47 \pm 8.67$ & $12.75 \pm 7.87$ & $18.37 \pm 13.30$ & $6.37 \pm 8.80$ & $16.25 \pm 14.82$ \\
\hline Lysozyme & $\mu \mathrm{g} / \mathrm{mL}$ & $5.52 \pm 1.25$ & $2.21 \pm 0.69 *$ & $6.05 \pm 0.87$ & $2.48 \pm 0.77 *$ & $4.82 \pm 0.96$ & $2.64 \pm 0.99^{*}$ \\
\hline $\mathrm{Cp}$ & $\mathrm{OD}_{540 \mathrm{~nm}}$ & $0.48 \pm 0.06$ & $0.69 \pm 0.10^{*}$ & $0.51 \pm 0.07$ & $0.31 \pm 0.08^{*}$ & $0.46 \pm 0.04$ & $0.32 \pm 0.09^{*}$ \\
\hline
\end{tabular}

$n=5$, mean \pm SD. Time after the end of intoxication

* Statistically significant at $P<0.05$

PHOS, ALP, TRIG and GGT) were similar to those found in the control fish plasma.

MC-intoxicated fish demonstrated a strong decrease in lysozyme levels after $24 \mathrm{~h}$ and $72 \mathrm{~h}$, reaching about $40 \%$ of its activity in the control group, with a slow rise detected after 5 days, when nearly $55 \%$ of the control activity was noted.

Marked increase in Cp activity, reaching 144\% of the OD value of the enzyme activity in control fish, was detected in plasma sampled $24 \mathrm{~h}$ after the end of intoxication. However, after $72 \mathrm{~h}, \mathrm{Cp}$ activity was lower than that in the control group, with the OD value reaching $61 \%$ of the control level, and the reduction was still observed after 5 days.

\section{Discussion}

It is believed that fish can be exposed to MCs during feeding with food containing cyanotoxins and to a lesser extent, through passive means, absorbing the toxins directly from the water (Butler et al. 2009; Cazenave et al. 2005). The second means of exposure is seldom used in experimental settings for $\mathrm{MC}$ toxicity assessment. In our study, for the first time, toxin-induced changes in blood parameters, including $\mathrm{Cp}$ and lysozyme activity, were assessed, after common carp immersion in water containing MCs under experimental conditions. The obtained results indicate that not only consumption of food containing toxins but also MCs dissolved in water may pose a threat to fish health.

After entering the body, MCs are transported via the bloodstream. The cellular uptake of the toxins is mediated by multispecific organic anion-transporting peptides (rodent Oatps; human OATPs) found to be expressed, for example, in liver or kidney (Campos and Vasconcelos 2010), which makes these organs susceptible to MC intoxication. MCs tend to accumulate in fish liver, reaching higher concentrations than in the other tissues (Li et al. 2007; Papadimitriou et al. 2010; Romo et al. 2011). The exception was the fish fed on cyanobacteria containing toxins, in which higher MC concentrations were detected in the intestinal walls than in the livers (Zhang et al. 2009; Chen et al. 2009a). In our study, the only organ in 
which the toxin was found was the liver. This confirmed the absorption of MCs into bodies of fish under applied experimental conditions. MCs were not detected in the other studied organs, which is inconsistent with previous studies indicating that the toxins may accumulate in relatively high concentrations in kidneys, while in gills and muscles, it may also be found, though at lower levels (Papadimitriou et al. 2010; Chen et al. 2009a; Cazenave et al. 2005). Cazenave et al. (2005) observed high MC concentrations in gills after Jenynsia multidentata and Corydoras paleatus exposure for $24 \mathrm{~h}$ to $50 \mu \mathrm{g} / \mathrm{L}$ of MC-RR dissolved in water, which were 0.56 and $1.40 \mu \mathrm{g} /$ g f.w., respectively. On the other hand, the toxin amounts in livers were also a few-fold higher (1.62 and $19.63 \mathrm{~g} / \mathrm{g}$ f.w.) than those detected in our study. There could be several reasons for these differences. The first one is the toxin dose, which in our experiment was more than four times lower. The second one is the toxin variant, as different variants can have varying accumulation abilities. It cannot be ruled out, however, that the toxin may have been present in other studied organs, though in much lower concentrations, being below the limit of detection of the used method.

Most of the observed changes in our study were connected with liver dysfunctions, which confirms toxic potency of MCs administered by immersion. As the only MC isoform detected in fish tissues was MCLR, it can be concluded that this toxin was responsible for the alterations observed in fish blood. The earliest symptom of hepatotoxicity was increased LDH activity, showing the tendency to rise in time, indicating the progressive damage of the organ. Besides high LDH levels, which are considered to be a useful marker of hepatocyte collapse (Hudder et al. 2007), also CK activity showed a similar profile. Circulating CK is removed by degradation in the liver, so the increase in the enzyme activity in plasma may be treated as a consequence of liver failure; however, it is rather a muscle or brain damage marker. The most distinct symptoms of hepatotoxic effects in exposed fish were highly elevated levels of AST and ALT, coupled with increased $\mathrm{NH}_{3}$ level, which also indicated the escalation of the liver damage process, lasting until the end of the experiment.

To some extent, similar biochemical changes were also found in the studies on crucian carp (Carassius auratus) (Zhang et al. 2007) or common carp (Kopp et al. 2009, 2010). In the study by Zhang et al. (2007), fish were injected intraperitoneally with MCs, which resulted in faster and more pronounced changes in the liver profile than those observed in our experiment. Besides the increase in LDH, AST and ALT levels, seen already in the first hours after toxin injection, also ALP, TP and TRIG exhibited significant changes. Moreover, depending on the used toxin dose, LDH, AST, ALT and ALP tended to decrease toward the end of the experiment, indicating a recovery trend. No such effects were seen in our study; on the contrary, rather the escalation of the liver damage was observed, which shows differences in MC toxicodynamics dependent on the exposure route.

The lack of more pronounced changes in blood cell parameters of intoxicated fish under the applied experimental protocol seems to confirm the conclusion reached by Kopp et al. (2010) that changes in blood morphology after fish intoxication with MCs observed in other studies (Palíková et al. 1998, Kopp et al. 2010) are probably the effects of extensive hemorrhaging caused by high doses of toxins or may be the result of oxygen decline during cyanobacterial blooms.

Lysozyme is one of the main components associated with the first line of immune defense in fish. The main sources of the enzyme are monocytes, macrophages and polymorphonuclear granulocytes, from which it is released into the blood (Murray and Fletcher 1976). Lysozyme activity in fish plasma is one of the sensitive biomarkers of environmental contamination (Bols et al. 2001). Decreased enzyme activity was reported after fish intoxication with, for example, heavy metals, but that drop was concomitant with a decrease in the leukocyte count. In our experiment, no changes in the total number of WBC were detected; however, a significant decrease in the monocyte count after $24 \mathrm{~h}$ was seen, with a subsequent slow increase later in the experimental period, which might reflect the lysozyme kinetics in fish blood plasma. Moreover, as previously found, MC-LR is able to modulate some vital functions of phagocytic cells in fish (Palíková et al. 1998; Sieroslawska et al. 2007), which may also result in changed enzyme production and release. Although it is difficult to speculate on the mechanisms of lysozyme activity depression, as they are probably complex, it should be noted that observed effects may result in weaker nonspecific defense reactions in fish living in the environment containing MC-LR and thus their increased susceptibility to bacterial diseases. 
$\mathrm{Cp}$ belongs to acute phase proteins, whose level changes in response to such stimuli as tissue damage or inflammation (Bols et al. 2001). In fish, the main function of $\mathrm{Cp}$, like in mammals, is copper transport in the blood. It also acts as an antioxidant of ferroxidase activity, which can oxidize ferrous iron $\left(\mathrm{Fe}^{2+}\right)$ into the nontoxic form of ferric $\left(\mathrm{Fe}^{3+}\right)$ (Fox et al. 2000). Ferrous iron, in the presence of hydrogen peroxide or molecular oxygen, possesses the ability to generate highly toxic hydroxyl and superoxide free radicals. The increase in Cp activity observed $24 \mathrm{~h}$ after the end of intoxication, in connection with other observed changes, confirms liver and possibly also other organ toxin-induced damages. Moreover, as MC-LR is known to generate oxidative stress in exposed cells (Gehringer 2004; Ding et al. 2000), we can speculate that the induction of $\mathrm{Cp}$ activity might be the part of protective mechanisms in fish, preventing iron-catalyzed hydroxyl radical formation. Such prevention against reactive oxygen species (ROS) formation by inhibition of Fenton reaction in hepatocytes intoxicated with MC-LR was reported after cell pretreatment with deferoxamine (DFO) (Ding et al. 2000). DFO belongs to specific iron chelators of effects similar to those induced by $\mathrm{Cp}$. However, later in the experiment, a severe decrease in the enzyme activity was observed, lasting to the end of the experimental period.

Initially, $\mathrm{Cp}$ is synthesized in hepatocytes as an apo-ceruloplasmin. Copper incorporation occurs in the liver later, before enzyme secretion into the blood. The failure of copper incorporation into $\mathrm{Cp}$ results in a loss of enzymatic activity and leads to rapid degradation by plasma proteases (Squitti et al. 2008 and references herein), so the observed effects may be a consequence of the impairment of liver functions manifested by disturbances in enzyme formation.

The oxidative stress is a consequence of both ROS overproduction and a decrease in antioxidant levels. The decrease in Cp activity observed in our study may contribute to the potentiation of the oxidative effects of MC-LR, as also another antioxidant, GSH, is known to be depleted by MCs (Ding and Ong 2003).

In conclusion, MC-LR appeared to be able to induce biochemical changes in carp exposed to the toxin by immersion, which confirms that fish may undergo intoxication by other means than consuming food containing cyanotoxins. Liver damage accounts for most of the observed changes, which is a common result of MC-LR poisoning. Additionally, detected changes in lysozyme and $\mathrm{Cp}$ activity may have distinct effects on resistance of fish to pathogens or oxidative stress.

Acknowledgments The authors would like to thank Ewelina Krawczak, Anna Kocova and Marie Pecena for their excellent technical assistance. This research was supported by the Polish Ministry of Science and Higher Education, Grant No. NN303606138, the centre CENAQUA No. CZ.1.05/2.1.00/ 01.0024 and Project No. USB (GAJU) No.047/2010/Z.

Open Access This article is distributed under the terms of the Creative Commons Attribution Noncommercial License which permits any noncommercial use, distribution, and reproduction in any medium, provided the original author(s) and source are credited.

\section{References}

Baganz D, Staaks G, Pflugmacher S, Steinberg CEW (2004) Comparative study of microcystin-LR-induced behavioral changes of two fish species, Danio rerio and Leucaspius delineatus. Environ Toxicol 19:564-570

Blaha L, Babica P, Marsalek B (2009) Toxins produced in cyanobacterial water blooms-toxicity and risks. Interdisc Toxicol 2:36-41

Blaha L, Blahova L, Kohoutek J, Adamovsky O, Babica P, Marsalek B (2010) Temporal and spatial variability of cyanobacterial toxins microcystins in three interconnected freshwater reservoirs. J Serb Chem Soc 75:1303-1312

Bols NC, Brubacher JL, Ganassin RC, Lee LE (2001) Ecotoxicology and innate immunity in fish. Dev Comp Immunol 25:853-873

Briand JF, Jacquet S, Bernard C, Humbert JF (2003) Health hazards for terrestrial vertebrates from toxic cyanobacteria in surface water ecosystems. Vet Res 34:361-377

Butler N, Carlisle JC, Linville R, Washburn B (2009) Microcystins: a brief overview of their toxicity and effects, with special reference to fish, wildlife, and livestock. California Environmental Protection Agency, Sacramento, p 5

Campos A, Vasconcelos V (2010) Molecular mechanisms of microcystin toxicity in animal cells. Int $\mathrm{J}$ Mol Sci 11:268-287

Carmichael WW, Azevedo SM, An JS, Molica RJR, Jochimsen EM, Lau S, Rinehart KL, Shaw GR, Eaglesham GK (2001) Human fatalities from cyanobacteria: chemical and biological evidence for cyanotoxins. Environ Health Perspect 109:663-668

Cazenave J, Wunderlin DA, de Los Angeles Bistoni M, Amé MV, Krause E, Pflugmacher S, Wiegand C (2005) Uptake, tissue distribution and accumulation of microcystin-RR in Corydoras paleatus, Jenynsia multidentata and Odontesthes bonariensis. A field and laboratory study. Aquat Toxicol 75:178-190

Chen J, Zhang D, Xie P, Wang Q, Ma Z (2009a) Simultaneous determination of microcystin contaminations in various 
vertebrates (fish, turtle, duck and water bird) from a large eutrophic Chinese lake, Lake Taihu, with toxic Microcystis blooms. Sci Total Environ 407:3317-3322

Chen J, Xie P, Li L, Xu J (2009b) First identification of the hepatotoxic microcystins in the serum of a chronically exposed human population together with indication of hepatocellular damage. Toxicol Sci 108:81-89

Day DR, Segars AL, Arendt MD, Lee AM, Peden-Adams MM (2007) Relationship of blood mercury levels to health parameters in the loggerhead sea turtle (Caretta caretta). Environ Health Perspect 115:1421-1428

Ding WX, Ong CN (2003) Role of oxidative stress and mitochondrial changes in cyanobacteria-induced apoptosis and hepatotoxicity. FEMS Microbiol Lett 220:1-7

Ding WX, Shen HM, Ong CN (2000) Critical role of reactive oxygen species and mitochondrial permeability transition in microcystin-induced rapid apoptosis in rat hepatocytes. Hepatology 32:547-555

Ernst B (2008) Investigations on the impact of toxic cyanobacteria on fish-as exemplified by the coregonids in lake Ammersee. Dissertation, Konstanzer Online-PublicationsSystem (KOPS)

Fox PL, Mazumdar B, Ehrenwald E, Mukhopadhyay CK (2000) Ceruloplasmin and cardiovascular disease. Free Radical Biol Med 28:1735-1744

Gehringer MM (2004) Microcystin-LR and okadaic acidinduced cellular effects: a dualistic response. FEBS Lett 557:1-8

Hudder A, Song W, O'Shea KE, Walsh PJ (2007) Toxicogenomic evaluation of microcystin-LR treated with ultrasonic irradiation. Toxicol Appl Pharmacol 220:357364

Jancula D, Mikovcova M, Adamek Z, Marsalek B (2008) Changes in the photosynthetic activity of Microcystis colonies after gut passage through Nile tilapia (Oreochromis niloticus) and silver carp (Hypophthalmichthys molitrix). Aquacult Res 39:311-314

Kopp R, Mares J, Kubicek Z, Babica P (2005) The influence of toxic cyanobacterial water blooms on the hematological indicators of silver carp (Hypophthalmichthys molitrix Val.). Oceanol Hydrobiol Stud 34(Supl.3):85-92

Kopp R, Mares J, Palikova M, Navratil S, Kubicek Z, Zikova A, Hlavkova J, Blaha L (2009) Biochemical parameters of blood plasma and content of microcystins in tissues of common carp (Cyprinus carpio L.) from a hypertrophic pond with cyanobacterial water bloom. Aquacult Res 40:1683-1693

Kopp R, Palikova M, Navratil S, Kubicek Z, Zikova A, Mares J (2010) Modulation of biochemical and haematological indices of silver carp (Hypophthalmichthys molitrix Val.) exposed to toxic cyanobacterial water bloom. Acta Vet Brno 79:135-146

Lawton LA, Edwards C, Codd GA (1994) Extraction and high performance liquid chromatographic method for the determination of microcystins in raw and treated waters. Analyst 119:1525-1530

Li XY, Chung IK, Kim JI, Lee JA (2004) Subchronic oral toxicity of microcystin in common carp (Cyprinus carpio L.) exposed to microcystis under laboratory conditions. Toxicon 44:821-827
Li S, Xie P, Xu J, Li L, Liang G, Zheng L (2007) Tissue distribution of microcystins in bighead carp via intraperitoneal injection. Bull Environ Contam Toxicol 79:297-300

Malbrouck C, Kestemont P (2006) Effects of microcystins on fish. Environ Toxicol Chem 25:72-86

Matsunaga H, Harada K-I, Senma M, Ito Y, Yasuda N, Ushida S, Kimura Y (1999) Possible cause of unnatural mass death of wild birds in a pond in Nishinomiya, Japan: sudden appearance of toxic cyanobacteria. Nat Toxins 7:81-84

Murray CK, Fletcher TC (1976) The immunohistochemical localization of lysozyme in plaice (Pleuronectes platessa L.) tissues. J Fish Biol 9:329-334

Oberemm A, Becker J, Codd G, Steinberg C (1999) Effects of cyanobacterial toxins and aqueous crude extracts on the development of fish and amphibians. Environ Toxicol 14:77-88

Palíková M, Kovároo F, Navrátil S, Kubala L, Pešák S, Vajcová V (1998) The effects of pure microcystin LR and biomass of blue-green algae on selected immunological indices of carp (Cyprinus carpio L.) and silver carp (Hypophthalmichthys molitrix Val.). Acta Vet Brno 67:265-272

Papadimitriou T, Kagalou I, Bacopoulos V, Leonardos ID (2010) Accumulation of microcystins in water and fish tissues: an estimation of risk associated with microcystins in most of the Greek Lakes. Environ Toxicol 25:418-427

Pawlik-Skowrońska B, Pirszel J, Kornijów R (2008) Spatial and temporal variation in microcystin concentrations during perennial bloom of Planktothrix agardhii in a hypertrophic lake. Int J Lim 44:145-150

Pelgrom SMGJ, Lock RAC, Balm PHM, Bonga W (1995) Integrated physiological response of tilapia to sublethal copper exposure. Aquat Toxicol 32:303-320

Qiu T, Xie P, Ke Z, Li L, Guo L (2007) In situ studies on physiological and biochemical responses of four fishes with different trophic levels to toxic cyanobacterial blooms in a large Chinese lake. Toxicon 50:365-376

Qiu T, Xie P, Guo L, Zhang D (2009) Plasma biochemical responses of the planktivorous filter-feeding silver carp (Hypophthalmichthys molitrix) and bighead carp (Aristichthys nobilis) to prolonged toxic cyanobacterial blooms in natural waters. Environ Toxicol Pharmacol 27:350-356

Romo S, Fernandez F, Ouahid Y, Baron-Sola A (2011) Assessment of microcystins in lake water and fish $(\mathrm{Mu}-$ gilidae, Liza sp.) in the largest Spanish coastal lake. Environ Monit Assess. doi:10.1007/s10661-011-2011-0

Sieroslawska A, Rymuszka A, Bownik A, Skowroński T (2007) The influence of microcystin-LR on fish phagocytic cells. Hum Exp Toxicol 26:1-5

Sivonen K, Jones G (1999) Cyanobacterial toxins. In: Chorus I, Bartram J (eds) Toxic cyanobacteria in water. E\&FN Spon, London, pp 41-111

Squitti R, Quattrocchi CC, Salustri C, Rossini PM (2008) Ceruloplasmin fragmentation is implicated in 'free' copper deregulation of Alzheimer's disease. Prion 2:23-27

Svobodova Z, Pravda D, Palackova J (1991) Unified methods of haematological examination of fish. Research Institute of Fish Culture and Hydrobiology Vodnany, Edition Methods No. 20

Xie L, Xie P, Guo L, Li L, Miyabara Y, Park H (2005) Organ distribution and bioaccumulation of microcystins in 
freshwater fish at different trophic levels from the eutrophic Lake Chaohu, China. Environ Toxicol 20:293-300

Zhang X, Xie P, Wang W, Li D, Shi Z (2007) Plasma biochemical responses of the omnivorous crucian carp (Carassius auratus) to crude cyanobacterial extracts. Fish Physiol Biochem 34:323-329
Zhang X, Xie P, Liu Y, Qiu T (2009) Transfer, distribution and bioaccumulation of microcystins in the aquatic food web in Lake Taihu, China, with potential risks to human health. Sci Total Environ 407:2191-2199 